\title{
Soil Physico-Chemical Properties and Fertility Status of Jantapur-1 Micro- watershed, Lingasugur Taluk, Raichur District (Karnataka State), India
}

\author{
B. Kumarnaik ${ }^{1}$, S. N. Bhat ${ }^{1 *}$, S. R. Balanagoudar ${ }^{1}$, N. L. Rajesh ${ }^{1}$ and S. R. Anand ${ }^{2}$ \\ ${ }^{1}$ Department of Soil Science and Agricultural Chemistry, UAS, \\ Raichur (Karnataka) -584 104, India \\ ${ }^{2}$ Department of Agronomy, UAS, Raichur (Karnataka) -584 104, India \\ *Corresponding author
}

\section{A B S T R A C T}

Fourteen representative mapping units representing upland, midland, mid

Keywords

Soil survey,

Mapping, Soil

fertility

Article Info

Accepted:

15 December 2019

Available Online:

20 January 2020 upland, lowland and near lowland in Jantapur-1 micro-watershed of Lingasugur taluk, Raichur district in Karnataka were characterized and assessed for their nutrients content. The soils were shallow in upper slope and deeper in the lower slopes. Colour of the soil is reddish brown to very grayish brown, moderately to excessive drained, neutral to strongly alkaline in reaction, low to medium in organic carbon and medium to high in cation exchange capacity with wide textural variations. Soils were low in available nitrogen, low to high in available phosphorus, potassium and sulphur. Whereas, available copper, iron and manganese were sufficient but soils were deficient in zinc.

\section{Introduction}

Soil fertility affects considerably the land use of any agro-ecosystem. The inherent fertility of soil is controlled by the set of pedogenic factors that vary from soil to soil. Declining soil fertility is the main cause for low land productivity. Present day exploitive agriculture, which not only increased crop yield but also depleted our soils of their nutrient reserve. Further, it resulted in the emergence of a number of nutrient deficiencies.
Watershed is a "geo-hydrological" entity or piece of land that drains at a common outlet. This natural unit is evolved through the interaction of the rainwater and land mass and normally comprises of arable and non-arable lands along with drainage lines. Thus, the watershed area is delineated based on distribution and flow of rainwater, which facilitates scientific developments of natural resources like soil, water and vegetation. The most important basic natural resource that determines the ultimate sustainability of any agricultural system is the soil. Jantapur-1 
micro-watershed in Raichur district of Karnataka was selected for this study as it has wide variety of soils. As the catchment area is an undulating terrain, it is quite likely that the land is subjected to different degrees of erosion resulting in varied depth of soils, making them fit for growing only a few set of crops. Keeping these factors in mind the study has been undertaken to characterize, classify and mapping the soils of Jantapur-1 micro watershed and to suggest the land use plan to protect the natural resources for sustainable crop production.

\section{Materials and Methods}

Semi arid climate prevails in Jantapur-1 micro-watershed and it belongs to North Eastern Dry Zone of Karnataka state. The average annual rainfall is $765.54 \mathrm{~mm}$. Mean maximum and minimum temperature is 34.50 ${ }^{\circ} \mathrm{C}$ and $22.68{ }^{\circ} \mathrm{C}$, respectively. The highest rainfall was received during the month of September $(197.11 \mathrm{~mm})$. The length of growing period, which indicates the availability of water for plant growth, is about 150 to 180 days in a year. It starts from the middle July and continues up to the end of December. The area qualifies for hyperthermic temperature regime. The extent of area and distribution of these management units are marked with a boundary on Jantapur-1 cadastral map. The high intensity survey at 1: 8000 scale was carried out in 624.27 ha area of the Jantapur-1 during 2016.

Horizonwise samples were collected and characterized for important physical and chemical parameters following standard procedures. Besides, 99 surface samples were also collected and these surface samples were analyzed for available macronutrients $(\mathrm{N}, \mathrm{P}$, $\mathrm{K}, \mathrm{S}, \mathrm{Ca}, \mathrm{Mg}, \mathrm{Na}, \mathrm{OC}, \mathrm{CaCO}_{3}$ etc.) and micronutrients ( $\mathrm{Fe}, \mathrm{Zn}, \mathrm{Cu}, \mathrm{Mn}$ ) by adopting standard procedures outlined by Jackson (1973) and Lindsay and Norvell (1978), respectively. The DTPA extractable micronutrients were rated as sufficient or deficient as per the limits suggested by Lindsay and Norvell (1978).

\section{Results and Discussion}

\section{Physico-chemical properties of soil series}

In red and black soil pedons, the bulk density varied from 1.40 to $1.52 \mathrm{Mg} \mathrm{m}^{-3}$ and 1.24 to $1.33 \mathrm{Mg} \mathrm{m}^{-3}$, respectively. In general, the bulk density of the lower solum was more than that of the upper. This could be attributed to clogging of pores by dispersed clays in subsoil layers. Similar results were quoted by Pulakeshi et al., (2014) for the soils of Mantagani village of Haveri district in Karnataka. Similar findings were also reported by Yeresheemi et al., (1997) in Upper Krishna command areas (Table 1).

The Porosity, in general, in red and black soil varied from 35.6 to 38.5 per cent and 49.6 to 53.2 per cent, respectively. According to Brady and Weil (2002), ideal total pore space for crop production, is around 50 per cent. Thus, most of soil series in the study area had nearly acceptable range of total porosity values for crop production. These present findings are in line with those of Ashenafi et al., (2010).

In red soil pedon, the maximum water holding capacity of the soils ranged between 35.3 to 41.6 per cent. These differences were due to the variation in the depth, clay, silt and organic carbon content of soils. These results are in line with those of Thangaswamy et al., (2005) in soils of Sivagiri village in Chittur district of Andhra Pradesh. Whereas, in black soil pedons, the maximum water holding capacity ranged from 41.7 to 51.7 per cent. Maximum water holding capacity increased from surface to the lower horizons and followed the trend of clay content and these 
results are in line with those of Nagendra and Patil (2015). In general, black soil pedons possessed higher water holding capacity values than red soils (Challa and Gaikwad, 1987).

The $\mathrm{pH}$ of red soils was neutral to slightly alkaline in reaction throughout the profile. In black soil series, the $\mathrm{pH}$ ranged from neutral to moderate alkaline in reaction. High $\mathrm{pH}$ in black soil pedons might be due to their calcareous nature and the accumulation of bases in the solum as they are poorly leached. In red soil pedons, large amount of bases have been leached out of the solum leaving behind iron and aluminum oxides and hence the $\mathrm{pH}$ in red soil pedons was less compared to their black soil. The $\mathrm{pH}$ increased with depth in both black and red soil pedons as the bases increased with depth. This may be ascribed to increasing content of exchangeable and soluble sodium and calcium with depth. Similar results were reported by Nagendra and Patil (2015).

In black and red soil series, the soluble salt content of the soils ranged from 0.19 to 0.43 $\mathrm{dSm}^{-1}$ and 0.12 to $0.16 \mathrm{dSm}^{-1}$, respectively. The soluble salt content generally increased with depth in black soils. The upper solum of black soils contained relatively low content than in the lower solum. This might be due to leaching of salts from the soil surface to lower depth due to rainfall or irrigation and their accumulation in lower depth. The soluble salt content was low in red soil compared to black soil, which indicated that red soil pedons were more leached compared to that of black soils.

Organic carbon content in red and black soil pedon series ranged from 1.80 to $4.79 \mathrm{~g} \mathrm{~kg}^{-1}$ and 2.39 to $5.79 \mathrm{~g} \mathrm{~kg}^{-1}$, respectively. The organic carbon content decreased with depth in all the pedons. The lower contents of organic carbon apparently resulted because of high temperature which induced rapid rate of organic matter oxidation. These observations are in the line with the findings of Basavaraju et al., (2005) in soils of Chandragiri Mandal of Chittor district of Andhra Pradesh.

The $\mathrm{CaCO}_{3}$ content in red and black soil pedon series ranged from 4.52 to 5.82 per cent and 9.43 to 15.31 per cent, respectively. In black soils, $\mathrm{CaCO}_{3}$ values were comparatively high than in red soils and shown increasing trend with depth. Similar research report was also made by Dasog (1975). The per cent free calcium carbonate in soils increased with depth; because, in semiarid condition calcium and magnesium get precipitated as their carbonates and bicarbonates in the solum. The results obtained in present study are in agreement with the findings of Pramod and Patil (2015).

\section{Fertility status of soil series}

Available $\mathrm{N}$ content in all the mapping units was low and decreased (113.5 to $207.8 \mathrm{~kg}$ ha $\left.{ }^{1}\right)$ with depth of pedons and this could be attributed to low organic carbon status coupled with low nitrogen fertilization application leading to nitrogen deficiency. These result obtained in the present study are in agreement with the findings of Mathews et al., (2009) and Sumitra et al., (2012). Nitrogen content was decreasing with the depth in all the soil pedons and this was correlated to organic carbon content, which decreased with depth.

The available phosphorous content in red soil series ranged from 18.4 to $32.2 \mathrm{~kg} \mathrm{ha}^{-1}$. Whereas, in black soil series ranged from 35.3 to $53.7 \mathrm{~kg} \mathrm{ha}^{-1}$. All the pedons of soil series recorded low to high content of available phosphorous and the phosphorus content decreased with depth in all the pedons. Similar results were also reported by Shiva Prasad et al., (1998), who reported low values were due to low CEC, clay content and soil reaction. 
Table.1 Physico-chemical properties of soil series of Jantapur-1 micro-watershed

\begin{tabular}{|c|c|c|c|c|c|c|c|c|c|}
\hline \multirow{2}{*}{$\begin{array}{l}\text { Mapping } \\
\text { units }\end{array}$} & \multirow[t]{2}{*}{ Horizon } & \multirow{2}{*}{$\begin{array}{c}\text { Depth } \\
\text { (cm) }\end{array}$} & \multirow{2}{*}{$\begin{array}{c}\text { BD } \\
\mathrm{Mg} \mathrm{m}^{-3}\end{array}$} & Porosity & MWHC & \multirow{2}{*}{$\underset{(1: 2.5)}{\text { pH }}$} & \multirow{2}{*}{$\begin{array}{c}\mathrm{EC} \\
\left(\mathrm{dSm}^{-1}\right)\end{array}$} & \multirow{2}{*}{$\begin{array}{c}\mathrm{OC} \\
\left(\mathrm{g} \mathrm{kg}^{-1}\right)\end{array}$} & \multirow{2}{*}{$\begin{array}{c}\text { Free } \\
\text { CaCO } \\
(\%)\end{array}$} \\
\hline & & & & \multicolumn{2}{|c|}{$\%$} & & & & \\
\hline \multicolumn{10}{|c|}{ Kumarkhed series red soil } \\
\hline \multirow[t]{3}{*}{ KMRfC2g2 } & Ap & $0-14$ & 1.43 & 37.9 & 35.3 & 7.11 & 0.12 & 1.80 & 4.52 \\
\hline & Apw & $14-28$ & 1.46 & 37.2 & 38.4 & 7.29 & 0.16 & 2.19 & 5.08 \\
\hline & $\mathrm{B} 1$ & $28-40$ & 1.52 & 35.6 & 41.6 & 7.35 & 0.15 & 2.79 & 5.43 \\
\hline SWA & & & 1.47 & 36.9 & 38.43 & 7.25 & 0.33 & 2.26 & 5.01 \\
\hline \multicolumn{10}{|c|}{ Thodki series red soil } \\
\hline THDfC2g3 & Ap & $0-18$ & 1.44 & 38.1 & 37.3 & 7.83 & 0.15 & 4.79 & 5.82 \\
\hline \multicolumn{10}{|c|}{ Chatra thanda series red soil } \\
\hline CHTfC2g1R2 & Ap & $0-22$ & 1.40 & 38.5 & 36.4 & 7.24 & 0.14 & 2.00 & 4.61 \\
\hline \multicolumn{10}{|c|}{ Jantapur series black soil } \\
\hline \multirow[t]{3}{*}{ JNTmB2g1 } & Ap & $0-9$ & 1.27 & 52.1 & 51.7 & 8.01 & 0.23 & 4.99 & 9.93 \\
\hline & Apw & $9-28$ & 1.29 & 51.3 & 48.0 & 8.19 & 0.26 & 4.39 & 10.35 \\
\hline & $\mathrm{B} 1$ & $28-45$ & 1.30 & 50.9 & 45.8 & 8.31 & 0.32 & 3.79 & 11.17 \\
\hline SWA & & & 1.28 & 51.43 & 48.5 & 8.17 & 0.27 & 4.39 & 10.48 \\
\hline \multicolumn{10}{|c|}{ Jantapur series black soil } \\
\hline \multirow[t]{2}{*}{ JNTfC2g2 } & Ap & $0-21$ & 1.28 & 51.7 & 50.0 & 8.36 & 0.29 & 4.39 & 12.27 \\
\hline & $\mathrm{B}$ & $21-39$ & 1.31 & 50.6 & 49.8 & 8.49 & 0.35 & 4.19 & 11.76 \\
\hline SWA & & & 1.29 & 51.15 & 49.9 & 8.43 & 0.32 & 4.29 & 12.01 \\
\hline \multicolumn{10}{|c|}{ Heggapur series black soil } \\
\hline \multirow[t]{5}{*}{ HEGmC2g2 } & AP & $0-9$ & 1.24 & 53.2 & 47.2 & 8.15 & 0.22 & 5.40 & 9.43 \\
\hline & Apw & $9-22$ & 1.26 & 52.5 & 44.4 & 8.25 & 0.26 & 4.39 & 10.28 \\
\hline & Bss1 & $22-40$ & 1.29 & 51.3 & 46.7 & 8.47 & 0.28 & 3.99 & 11.08 \\
\hline & Bss2 & $40-60$ & 1.31 & 50.6 & 42.7 & 8.56 & 0.34 & 3.39 & 11.32 \\
\hline & Bss3 & $60-72$ & 1.33 & 49.8 & 40.8 & 8.21 & 0.33 & 2.99 & 12.17 \\
\hline SWA & & & 1.28 & 51.48 & 44.36 & 8.33 & 0.28 & 4.03 & 10.85 \\
\hline \multicolumn{10}{|c|}{ Kalamalli series black soil } \\
\hline \multirow[t]{5}{*}{ KMLfC2g2S1 } & Ap & $0-12$ & 1.27 & 52.8 & 48.8 & 7.88 & 0.26 & 5.29 & 12.34 \\
\hline & Apw & $12-29$ & 1.29 & 51.3 & 46.2 & 8.13 & 0.29 & 4.19 & 12.93 \\
\hline & Bss1 & $29-50$ & 1.30 & 50.9 & 45.1 & 8.29 & 0.32 & 3.59 & 13.78 \\
\hline & Bss2 & $50-78$ & 1.32 & 50.2 & 44.6 & 8.41 & 0.35 & 3.39 & 14.15 \\
\hline & Bss3 & $78-100$ & 1.33 & 49.8 & 42.4 & 8.55 & 0.43 & 2.79 & 15.31 \\
\hline SWA & & & 1.30 & 50.86 & 45.42 & 8.25 & 0.34 & 3.91 & 13.70 \\
\hline \multicolumn{10}{|c|}{ Nagalapur series black soil } \\
\hline \multirow[t]{5}{*}{ NAGmB2 } & Ap & $0-18$ & 1.26 & 52.5 & 46.9 & 8.15 & 0.19 & 5.39 & 11.71 \\
\hline & Apw & $18-35$ & 1.27 & 52.1 & 47.4 & 8.29 & 0.21 & 4.99 & 12.25 \\
\hline & Bss1 & $35-50$ & 1.29 & 51.3 & 46.6 & 8.41 & 0.23 & 5.59 & 13.63 \\
\hline & Bss2 & $50-62$ & 1.31 & 50.9 & 42.3 & 8.53 & 0.27 & 3.19 & 14.48 \\
\hline & Bss3 & $62-80$ & 1.32 & 50.2 & 41.7 & 8.66 & 0.30 & 2.39 & 14.79 \\
\hline SWA & & & 1.28 & 51.46 & 44.98 & 8.40 & 0.24 & 4.31 & 13.37 \\
\hline
\end{tabular}


Table.2 Fertility status of the soil series of Jantapur-1 micro-watershed

\begin{tabular}{|c|c|c|c|c|c|c|c|c|c|c|}
\hline \multirow[t]{2}{*}{$\begin{array}{l}\text { Mapping } \\
\text { units }\end{array}$} & \multirow[t]{2}{*}{ Horizon } & \multirow[t]{2}{*}{$\begin{array}{c}\text { Depth } \\
\text { (cm) }\end{array}$} & \multicolumn{3}{|c|}{$\begin{array}{l}\text { Available nutrients } \\
\qquad\left(\mathrm{kg} \mathrm{ha}^{-1}\right)\end{array}$} & \multirow{2}{*}{$\begin{array}{c}\text { Avail. } \\
\text { S } \\
\text { (ppm) }\end{array}$} & \multicolumn{4}{|c|}{ DTPA extractable $\left(\mathrm{mg} \mathrm{kg}^{-1}\right)$} \\
\hline & & & $\mathbf{N}$ & $\mathbf{P}_{2} \mathbf{O}_{5}$ & $\mathbf{K}_{2} \mathbf{O}$ & & Zn & Fe & Mn & $\mathrm{Cu}$ \\
\hline \multicolumn{11}{|c|}{ Kumarkhed series red soil } \\
\hline \multirow[t]{3}{*}{ KMRfC2g2 } & Ap & $0-14$ & 176.4 & 23.0 & 309.1 & 8.6 & 0.09 & 10.20 & 5.42 & 0.45 \\
\hline & Apw & $14-28$ & 169.7 & 19.9 & 322.6 & 7.7 & 0.23 & 10.40 & 5.69 & 0.56 \\
\hline & $\mathrm{B} 1$ & $28-40$ & 153.8 & 18.4 & 268.8 & 7.0 & 0.24 & 10.86 & 6.13 & 0.37 \\
\hline SWA & & & 166.63 & 20.43 & 300.16 & 7.76 & 0.19 & 10.48 & 5.75 & 0.46 \\
\hline \multicolumn{11}{|c|}{ Thodki series red soil } \\
\hline THDfC2g3 & Ap & $0-18$ & 151.3 & 30.7 & 282.2 & 11.5 & 0.08 & 10.50 & 5.11 & 0.21 \\
\hline \multicolumn{11}{|c|}{ Chatra thanda series red soil } \\
\hline CHTfC2g1R2 & Ap & $0-22$ & 176.1 & 32.2 & 336.0 & 8.0 & 0.01 & 9.84 & 5.44 & 0.30 \\
\hline \multicolumn{11}{|c|}{ Jantapur series black soil } \\
\hline \multirow[t]{3}{*}{ JNTmB2g1 } & Ap & $0-9$ & 163.6 & 46.0 & 577.9 & 13.9 & 0.09 & 4.54 & 3.01 & 0.30 \\
\hline & Apw & $9-28$ & 144.2 & 43.0 & 551.0 & 12.9 & 0.20 & 5.00 & 3.12 & 0.33 \\
\hline & B1 & $28-45$ & 138.8 & 41.4 & 537.6 & 11.3 & 0.07 & 4.56 & 4.20 & 0.29 \\
\hline SWA & & & 148.86 & 43.46 & 555.5 & 12.7 & 0.12 & 4.70 & 3.44 & 0.31 \\
\hline \multicolumn{11}{|c|}{ Jantapur series black soil } \\
\hline \multirow[t]{2}{*}{ JNTfC2g2 } & Ap & $0-21$ & 125.3 & 52.2 & 524.2 & 20.7 & 0.04 & 5.32 & 4.67 & 0.20 \\
\hline & B1 & $21-39$ & 113.5 & 44.5 & 497.3 & 19.3 & 0.23 & 4.51 & 13.24 & 0.22 \\
\hline SWA & & & 119.4 & 48.35 & 510.75 & 20.0 & 0.14 & 4.90 & 8.96 & 0.21 \\
\hline \multicolumn{11}{|c|}{ Heggapur series black soil } \\
\hline \multirow[t]{5}{*}{ HEGmC2g2 } & AP & $0-9$ & 188.6 & 47.6 & 551.0 & 23.6 & 0.12 & 6.34 & 5.04 & 0.12 \\
\hline & Apw & $9-22$ & 176.2 & 44.5 & 510.7 & 20.7 & 0.07 & 6.06 & 4.89 & 0.43 \\
\hline & Bss1 & $22-40$ & 169.4 & 41.4 & 457.0 & 17.7 & 0.05 & 5.82 & 4.46 & 0.36 \\
\hline & Bss2 & $40-60$ & 151.9 & 41.1 & 443.5 & 14.8 & 0.06 & 5.62 & 4.14 & 0.32 \\
\hline & Bss3 & $60-72$ & 144.2 & 35.3 & 416.6 & 10.9 & 0.04 & 4.30 & 4.01 & 0.36 \\
\hline SWA & & & 166.06 & 41.98 & 475.76 & 17.54 & 0.06 & 6.82 & 3.91 & 0.32 \\
\hline \multicolumn{11}{|c|}{ Kalamalli series black soil } \\
\hline \multirow[t]{5}{*}{ KMLfC2g2S1 } & Ap & $0-12$ & 207.8 & 52.3 & 685.4 & 21.5 & 0.12 & 6.78 & 16.18 & 0.22 \\
\hline & Apw & $12-29$ & 194.1 & 47.6 & 712.3 & 18.1 & 0.15 & 6.12 & 14.11 & 0.29 \\
\hline & Bss1 & $29-50$ & 169.6 & 44.5 & 658.6 & 15.2 & 0.06 & 5.94 & 12.66 & 0.34 \\
\hline & Bss2 & $50-78$ & 163.9 & 41.4 & 618.2 & 12.1 & 0.04 & 5.26 & 4.58 & 0.45 \\
\hline & Bss3 & $78-100$ & 144.2 & 38.4 & 604.8 & 9.6 & 0.03 & 4.28 & 6.90 & 0.26 \\
\hline SWA & & & 175.92 & 44.80 & 655.86 & 15.30 & 0.03 & 7.47 & 10.89 & 0.31 \\
\hline \multicolumn{11}{|c|}{ Nagalapur series black soil } \\
\hline \multirow[t]{5}{*}{ NAGmB2 } & Ap & $0-18$ & 182.4 & 53.7 & 577.9 & 20.7 & 0.15 & 6.82 & 7.64 & 0.37 \\
\hline & Apw & $18-35$ & 169.7 & 49.1 & 537.6 & 18.6 & 0.12 & 6.64 & 6.07 & 0.12 \\
\hline & Bss 1 & $35-50$ & 163.2 & 44.5 & 510.7 & 14.7 & 0.03 & 6.34 & 5.05 & 0.32 \\
\hline & Bss2 & $50-62$ & 151.6 & 43.0 & 497.3 & 12.7 & 0.03 & 6.10 & 5.43 & 0.25 \\
\hline & Bss3 & $62-80$ & 132.3 & 36.8 & 470.4 & 10.1 & 0.01 & 5.44 & 6.23 & 0.20 \\
\hline SWA & & & 159.84 & 45.42 & 518.78 & 15.35 & 0.07 & 6.35 & 6.08 & 0.23 \\
\hline
\end{tabular}


Table.3 Status of soil fertility in surface samples of Jantapur-1 micro-watershed $(N=99)$

\begin{tabular}{|c|c|c|c|}
\hline Parameter & Range & SD & Average \\
\hline pH $(1: 2.5)$ & $6.14-8.80$ & 0.67 & 7.69 \\
\hline $\mathrm{EC}\left(\mathrm{dS} \mathrm{m} \mathbf{m}^{-1}\right)$ & $0.10-1.20$ & 0.16 & 0.20 \\
\hline $\mathrm{OC}\left(\mathrm{g} \mathrm{kg}^{-1}\right)$ & $1.20-5.99$ & 1.46 & 3.39 \\
\hline Available $\mathbf{N}\left(\mathrm{kg} \mathrm{ha}^{-1}\right)$ & $113-263$ & 43.28 & 195.02 \\
\hline Available $\mathrm{P}_{2} \mathrm{O}_{5}\left(\mathrm{~kg} \mathrm{ha}^{-1}\right)$ & $10.1-39.4$ & 5.47 & 20.12 \\
\hline Available $\mathrm{K}_{2} \mathrm{O}\left(\mathrm{kg} \mathrm{ha}^{-1}\right)$ & $313.6-593.6$ & 90.6 & 428.57 \\
\hline Available $S$ ( $\left.\mathrm{mg} \mathrm{kg}^{-1}\right)$ & $5.1-30.0$ & 5.19 & 10.58 \\
\hline $\begin{array}{l}\text { Exchangeable calcium } \\
\text { cmol }\left(p^{+}\right) \mathbf{k g}^{-1}\end{array}$ & $10.5-43.0$ & 14.29 & 24.41 \\
\hline $\begin{array}{l}\text { Exchangeable magnesium } \\
\text { cmol }\left(\mathbf{p}^{+}\right) \mathrm{kg}^{-1}\end{array}$ & $4.5-33.0$ & 6.24 & 12.14 \\
\hline \multicolumn{4}{|c|}{ DTPA extractable micronutrient } \\
\hline $\mathrm{Cu}\left(\mathrm{mg} \mathrm{kg}^{-1}\right)$ & $0.02-1.79$ & 0.33 & 0.52 \\
\hline $\operatorname{Mn}\left(\mathrm{mg} \mathrm{kg}^{-1}\right)$ & $1.59-19.29$ & 4.01 & 7.76 \\
\hline $\mathrm{Fe}\left(\mathrm{mg} \mathrm{kg}{ }^{-1}\right)$ & $0.14-11.47$ & 1.99 & 2.25 \\
\hline $\mathrm{Zn}\left(\mathrm{mg} \mathrm{kg}^{-1}\right)$ & $0.01-1.25$ & 0.17 & 0.20 \\
\hline
\end{tabular}


Fig.1 Available nitrogen status in surface soils of Jantapur-1 MWS

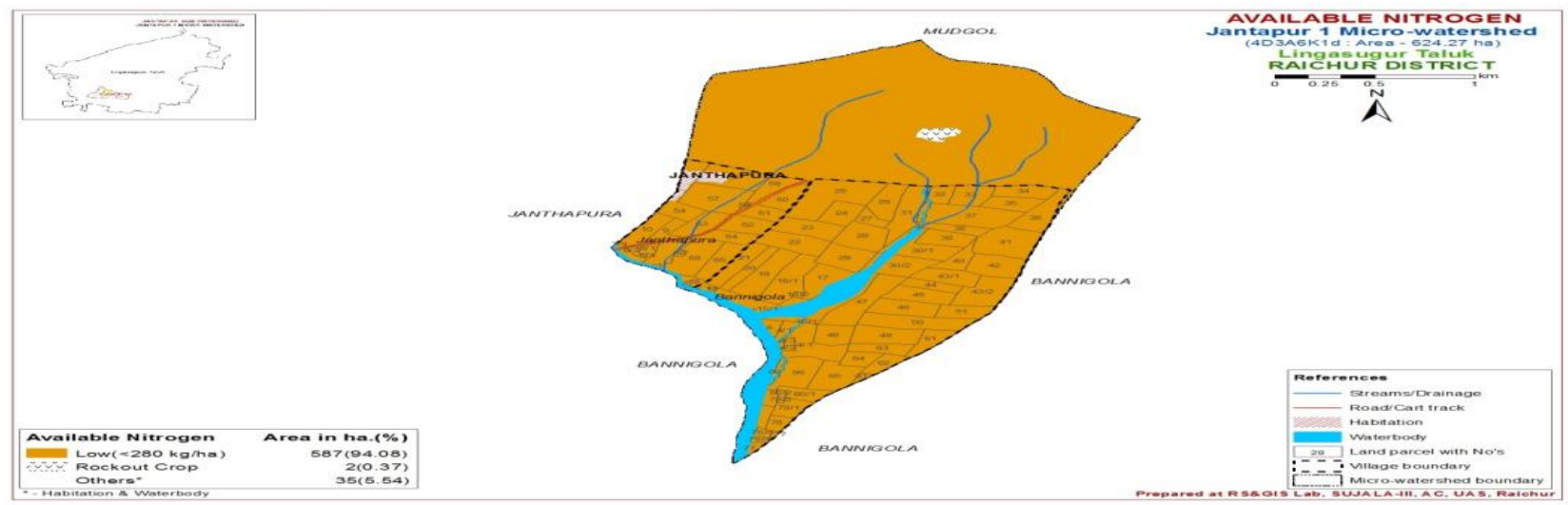

Fig.2 Available phosphorous status in surface soils of Jantapur-1 MWS

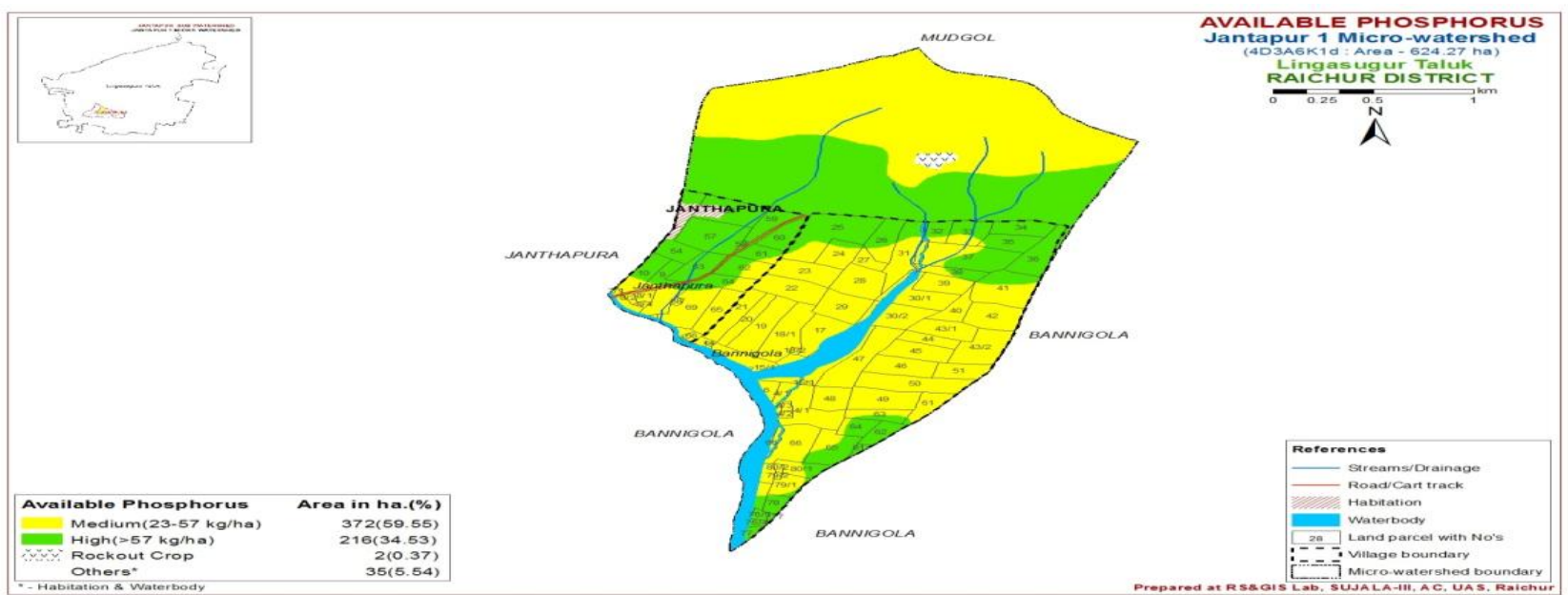

Fig.3 Available potassium status in surface soils of Jantapur-1 MWS

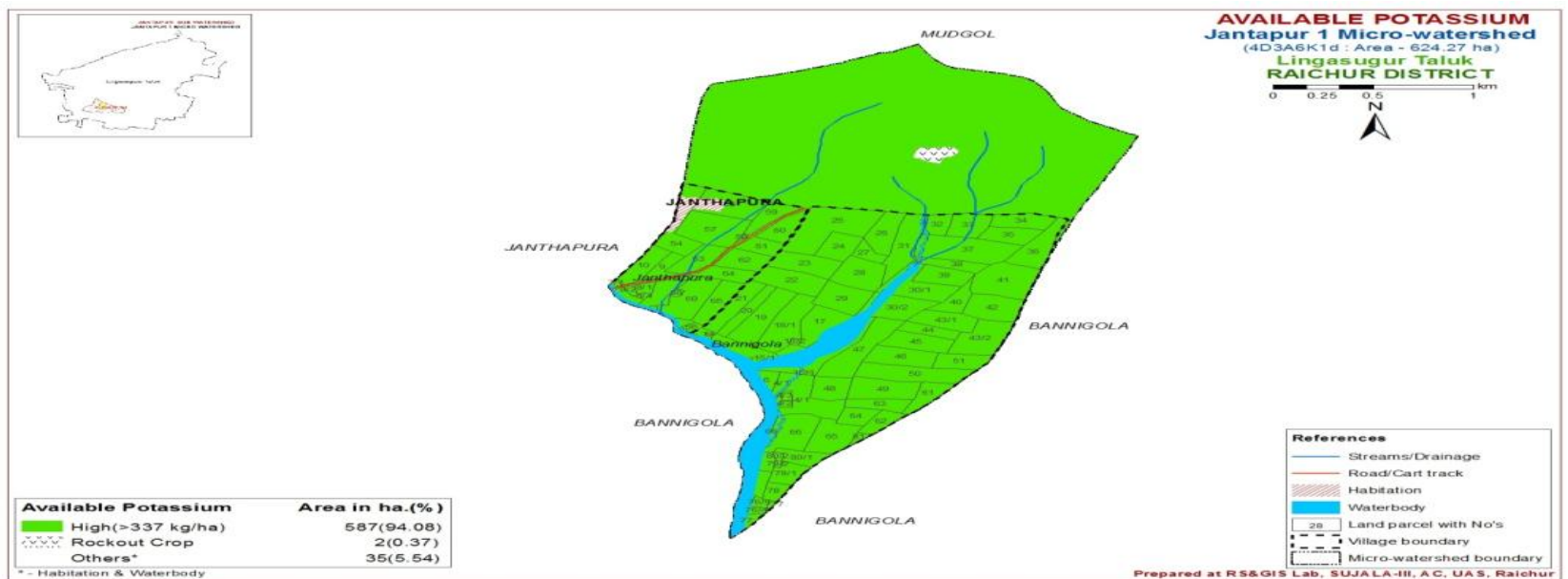


Fig.4 Available sulphur status in surface soils of Jantapur-1 MWS

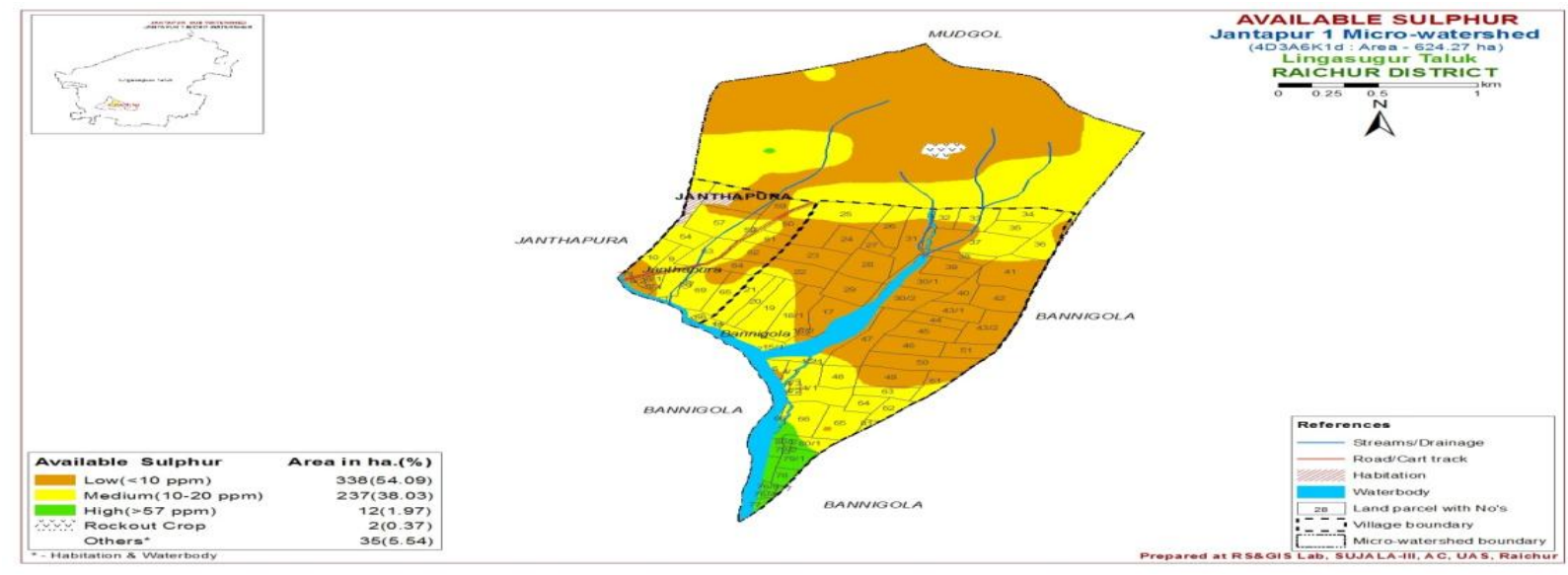

Fig.5 DTPA extractable copper status in surface soils of Jantapur-1 MWS

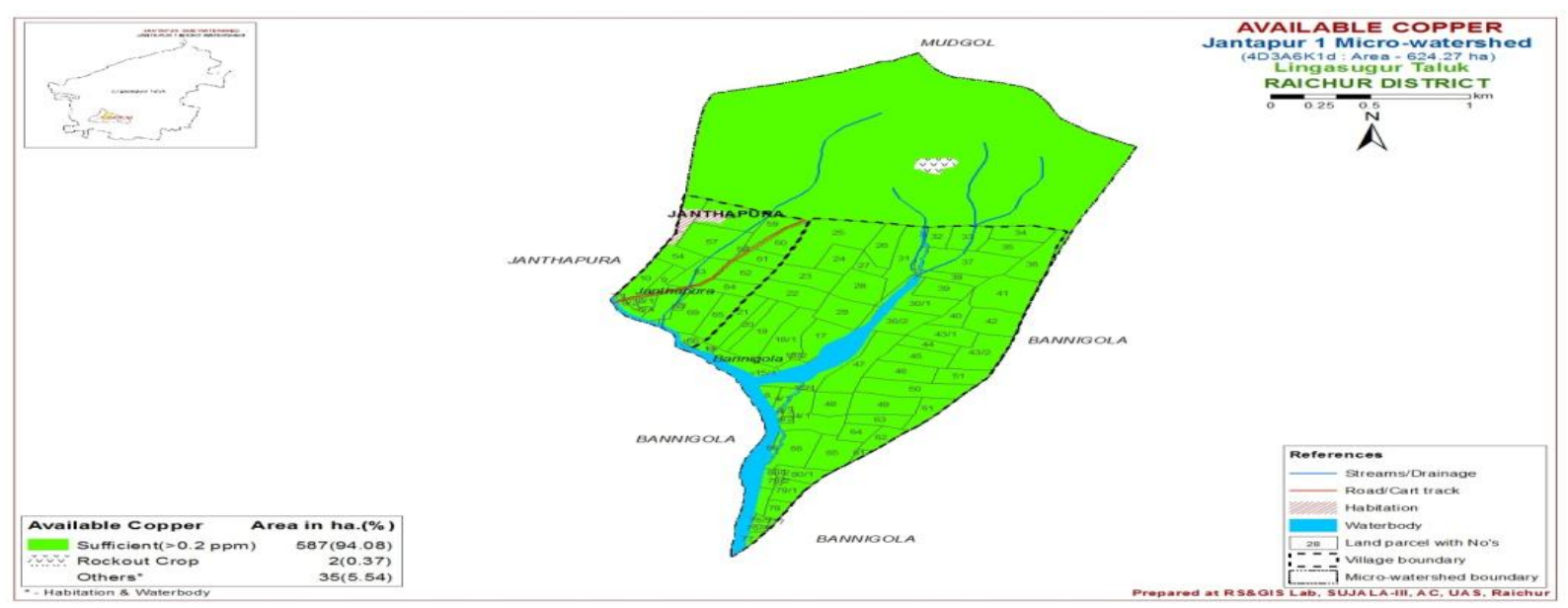

Fig.6 DTPA extractable manganese status in surface soils of Jantapur-1 MWS

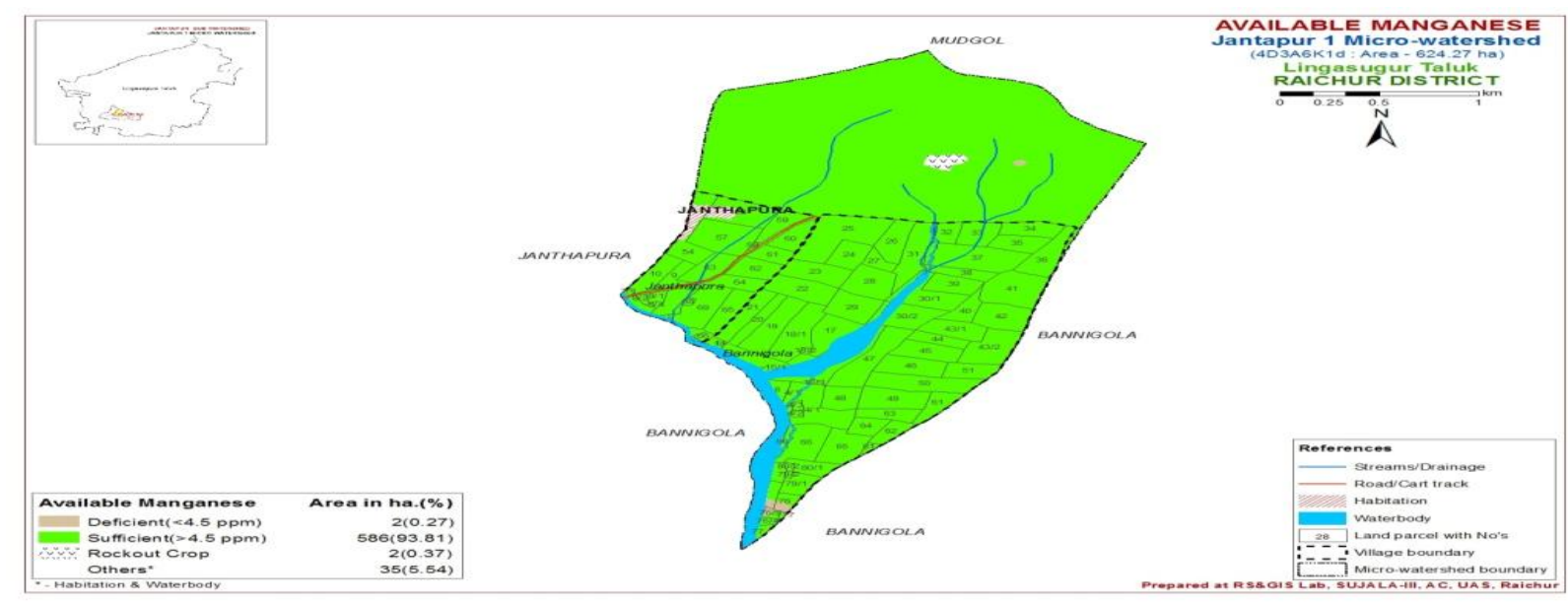


Fig.7 DTPA extractable iron status in surface soils of Jantapur-1 MWS

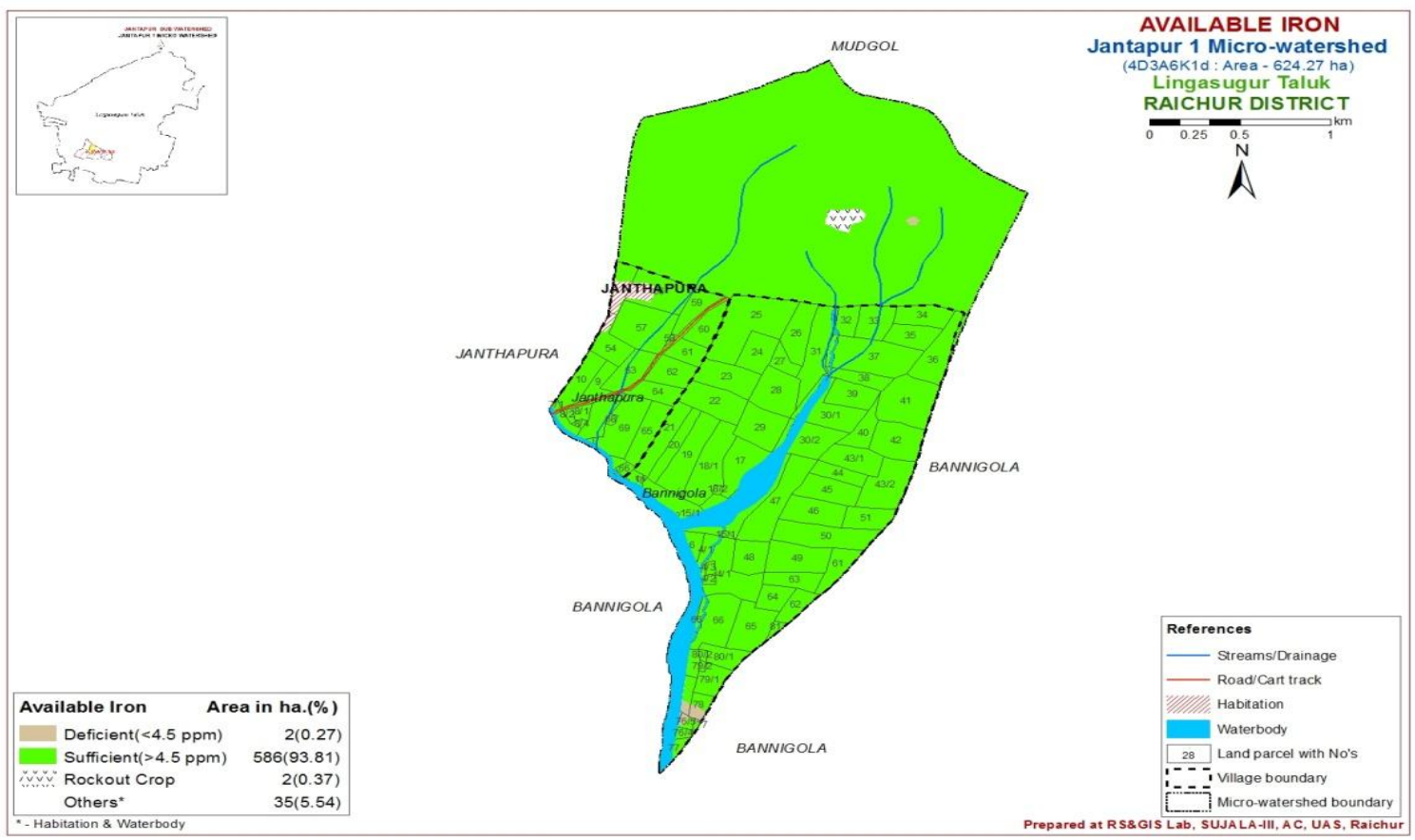

Fig.8 DTPA extractable zinc status in surface soils of Jantapur-1

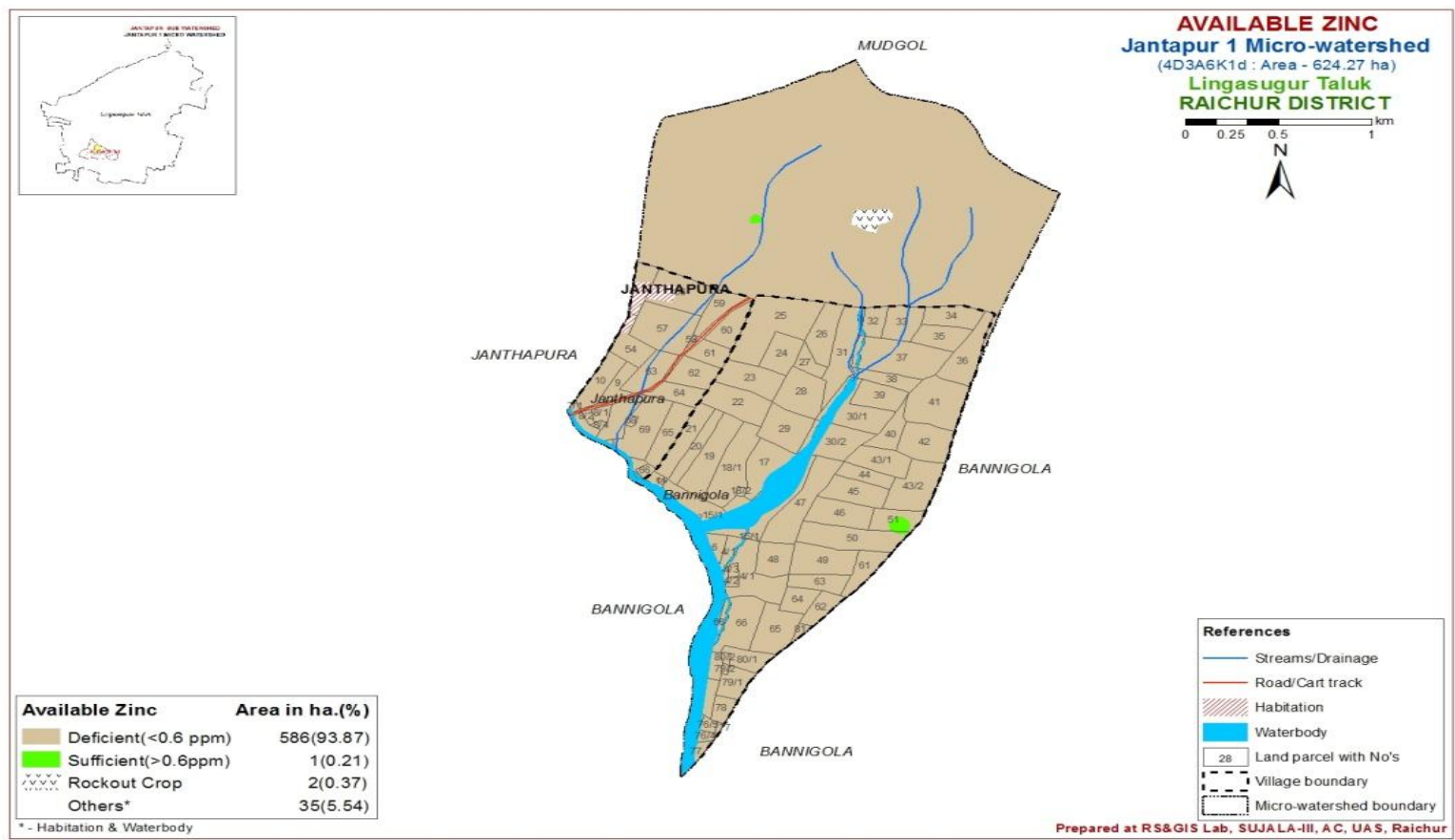

The available phosphorus content decreased with the depth and is attributed to its higher removal than replenishment in sub soils as well as due to higher phosphorous fixation capacity (Sathish and Badrinath, 1994). 
The content of available potassium in red soil series ranged from 282.2 to $336.0 \mathrm{~kg} \mathrm{ha}^{-1}$. Whereas, in black soil series its value ranged from 416.6 to $712.3 \mathrm{~kg} \mathrm{ha}^{-1}$, which is categorized as medium to high and it follows the decreasing trend with the depth. Black soil series showed higher values (416.6 to 712.3 $\mathrm{kg} \mathrm{ha}^{-1}$ ) than red soil series (282.2 to $336.0 \mathrm{~kg}$ $\mathrm{ha}^{-1}$ ) which might be due to predominance of $\mathrm{K}$ rich micaceous and feldspars minerals in parent material and application of $\mathrm{K}$ fertilizers and upward translocation of potassium from lower depths along with capillary raise of ground water.

The available sulphur content in both red and black soil series ranged from 7.0 to $11.5 \mathrm{ppm}$ and 10.1 to $23.6 \mathrm{ppm}$ which is categorized as low to high. The content of available sulphur was more in surface horizons than in subsurface due to higher amounts of organic matter in surface layers than in deeper layers. Similar results were reported by Mahesh (2016).

The DTPA-extractable copper ( 0.21 to 0.56 $\mathrm{mg} \mathrm{kg}{ }^{-1}$ ) and manganese (4.01 to $16.18 \mathrm{mg}$ $\mathrm{kg}^{-1}$ ) were found to be sufficient in majority of soils in the study area as these nutrients are well above their critical limits of 0.2 and 2.0 mg $\mathrm{kg}^{-1}$, respectively. Raghupathi (1989) reported that available copper content in North Karnataka soils ranged from 0.4 to 1.2 $\mathrm{mg} \mathrm{kg}^{-1}$.

The DTPA-extractable Fe content varied from 4.28 to $10.86 \mathrm{mg} \mathrm{kg}^{-1}$ soil. According to the critical limit of $2.5 \mathrm{mg} \mathrm{kg}^{-1}$ (Lindsay and Norvell, 1978), the soils were sufficient in available iron. The DTPA-extractable $\mathrm{Zn}$ ranged from 0.01 to $0.32 \mathrm{mg} \mathrm{kg}^{-1}$ soil. In all the pedons $\mathrm{Zn}$ content was under low category indicating the soils are deficient in $\mathrm{Zn}$. There was no definite trend for the distribution of these micronutrients with respect to depth.

\section{Fertility Status of Surface Soils( Table 3)}

The $\mathrm{pH}$ value of surface soils ranged from 6.14 to 8.80 with an average of 7.69 and standard deviation 0.67 . Soils contained low mount of total soluble salts, which varied from 0.10 to $1.20 \mathrm{dSm}^{-1}$ with an average of $0.20 \mathrm{dSm}^{-1}$. The organic carbon content in surface soils ranged from 1.20 to $5.99 \mathrm{~g} \mathrm{~kg}^{-1}$, which belongs to low to medium range as per soil fertility ratings. The soils were low to medium in available $\mathrm{N}, \mathrm{P}_{2} \mathrm{O}_{5}$ and $\mathrm{S}$ (Fig. 1, 2 \& 4) as well as high in available potassium (Fig. 3). The content of available zinc in surface soils was low; value ranged from 0.01 to $1.25 \mathrm{mg} \mathrm{kg}^{-1}$ (Fig. 8). The content of available iron in surface soils, ranged from 0.14 to $11.47 \mathrm{mg} \mathrm{kg}^{-1}$ with an average of 2.25 $\mathrm{mg} \mathrm{kg}^{-1}$ (Fig. 7) and manganese from 1.59 to $19.29 \mathrm{mg} \mathrm{kg}^{-1}$ with an average value of 7.76 $\mathrm{mg} \mathrm{kg}^{-1}$ (Fig. 6).

In conclusion, the soils of the study area differed in nutrient status and the fertilizer use should be planned on the basis of site-specific fertility status and nutrient-requirement of the crops. The $\mathrm{pH}$ of soils of Jantapur-1 microwatershed ranged from 7.11 to 8.66 indicating that soils were neutral to moderate alkaline and free of salinity. Soils were low to high in organic carbon content which increased with depth. The texture of black soils was finer than red soils. In all the soils, clay and silt content was increased with depth, fine and coarse sand content was decreased with the depth. The bulk density of the sub surface layers was more than the surface layer. The maximum water holding capacity of red and black soils varied. In black and red soil series water holding capacity increased with depth, because of increase in clay content. The calcium carbonate content increased with depth. Soils were low to medium in available nitrogen, phosphorus and sulphur and high in available potassium. Whereas, the content of available copper, iron, manganese were 
sufficient level but soils were deficient in zinc.

\section{References}

Ashenafi, A., Abayneh, E. and Sheleme, 2010, Characterizing Soils of Delbo Wegene Watershed, Wolaita Zone, Southern Euthiopia for planning appropriate land management. J. Sci. Environ. Mgt., 1(8): 184-199.

Basavaraju, D., Naidu, M. V. S., Ramavatharam, N., Venkaiah, K., Ramarao, G. and Reddy, K.S., 2005, Characterization, classification and evaluation of soils in Chandragiri mandal of Chittoor district, Andhra Pradesh. Agropedology, 15(1): 55-62.

Brady, N. C. and Weil, R. R., 2002, The Nature and Properties of Soils. $\left(13^{\text {th }}\right.$ Edn) Prentice Hall Inc, New Jersey. pp. 445-450.

Challa, O. and Gaikwad, M. S., 1987, Water relation characteristics of major soils of Dadra and Nagar Havali. J. Indian Soc. Soil Sci., 35: 118-120.

Dasog, G. S., 1975, Studies on genesis and classification of some black soils of command areas of Ghataprabha and Malaprabha Project. M. Sc. (Agri.) Thesis, Unvi. Agril. Sci., Bangalore, Karnataka (India).

Lindsay, W. L. and Norwell, W. A., 1978, Development of a DTPA soil test for zinc, iron, manganese and copper. Soil Sci. Soc. American J., 42: 421-428.

Mahesh., 2016, Soil resources inventory of Dongaraga on micro-watershed for land capability classification and crop suitability using remote sensing techniques. M. Sc. (Agri.) Thesis, Univ. Agric. Sci., Raichur, Karnataka (India).

Mathews, D., Patil, P. L., and Dasog, G. S., 2009, Identification of soil fertility constraints of a pilot site in coastal agro ecosystem of Karnataka by geographic information system technique.

Karnataka J. Agric. Sci., 22(1): 77-80.

Nagendra, B. R. and Patil, P. L., 2015, Characterization and classification of soil resource of Shirol West-1 microwatershed. Karnataka J. Agric. Sci., 28(4): 504-509.

Pramod, T. and Patil, P. L., 2015, Characterization and classification of soil resources of Balapur microwatershed. Karnataka J. Agric. Sci., 28(4): 510-517.

Pulakeshi, H. B. P., Patil, P. L. and Dasog, S., 2014, Characterization and classification of soil resources derived from chlorite schist in Northern Transition Zone of Karnataka. Karnataka J. Agric. Sci., 27(1): 14-21.

Raghupathi, H. B., 1989, Investigation on soil copper and crop response in selected soils of Karnataka. M. Sc. (Agri.) Thesis, Univ. Agric. Sci., Dharwad, India.

Sathish, G. C. and Badrinath, M. S., 1994, Characterization of soils of Western ghats in Dakshina Kannada district, Karnataka. Agropedology, 4: 45-48.

Shivaprasad, Reddy, R. S., Sehgal, J. and Velyutham, M. M., 1998, Interpretation for soil and land resource management. Annual Rep., NBSS and LUP, 47: 6568.

Sumitra, K. N., Budihal, S. L., Patil, S. G., Desai, B. K. and Bellakki, M. A., 2012, Soils, their distribution and productivity potentials and land evaluation: A case study at Timanhal micro-watershed, Kushtagi taluk. M. Sc. (Agri.) Thesis, Univ. Agril. Sci., Raichur, Karnataka (India).

Thangasamy, A., Naidu, M. V. S., Ramavatharam, N. and Raghava reddy, C., 2005, Characterization, classification and evaluation of soil resources in Sivagiri micro-watershed of Chittoor district in Andhra Pradesh 
for sustainable land use planning. $J$. Indian Soc. Soil Sci., 53(1): 11-21.

Yeresheemi, A. N., Channal, H. T., Patagundi, M. S. and Satyanarayana, T.,
1997, Salt affected soils of upper Krishna command Karnataka-I. Physical and chemical characteristics. Agropedology, 7: 213-221.

\section{How to cite this article:}

Kumarnaik, B., S. N. Bhat, S. R. Balanagoudar, N. L. Rajesh and Anand, S. R. 2020. Soil Physico-Chemical Properties and Fertility Status of Jantapur-1 Micro-watershed, Lingasugur Taluk, Raichur District (Karnataka State). Int.J.Curr.Microbiol.App.Sci. 9(01): 2077-2088. doi: https://doi.org/10.20546/ijcmas.2020.901.236 